\title{
Skill Learning Engineering Reading English Through Metacognitive Strategy In Industrial Era 4.0
}

\author{
Riyan Dwi Cahyaningsih ${ }^{1}$, Januarius Mujiyanto ${ }^{2}$, Muhammad Khumaedi ${ }^{3}$ \\ \{riyan.dwicahyaningsih@yahoo.com1, yanmujiyanto@mail.unnes.ac.id ${ }^{2}$, \\ muhammad_khumaedi@mail.unnes.ac.id ${ }^{3}$ \} \\ ${ }^{1}$ Student of Pascasarjana Negeri Semarang University, ${ }^{2}$ Professor Sastra Inggris of Negeri Semarang \\ University, ${ }^{3}$ Doctor Teknik Mesin education of Negeri Semarang University
}

\begin{abstract}
The purpose of this study the first is to find out about the current English reading learning. Second, knowing the pattern of learning to read English through metacognitive strategies in the industrial era 4.0. The method used in this study is descriptive qualitative method. Data analysis uses Miles and Huberman theory, namely data reduction, data presentation, and conclusion . The results of this study are, first, learning to read English at this time requires appropriate strategies and appropriate to the needs or the world of work, one of them is the use of metacognitive strategies. Secondly, in the digital era and experiencing acceleration now the learning pattern of reading English texts needs to be done continuously because in the digital era requires good and appropriate reading skills in accordance with the understanding of text content, metacognitive strategies are one solution to overcome reading problems in the industrial era.
\end{abstract}

Keywords: Learning, Reading, English, Metacognitive, Industry 4.0.

\section{Introduction}

Learning English is now important to be mastered by every human being to improve the ability to read it in understanding existing problems. Issues regarding events, information, and reading materials that tend to exist quickly and easily obtained by students make the importance of understanding the mastery of good English by these students. Now the English learning is available in every subject in the study program that organizes learning. There is no bargaining value in learning English because the demands of technology that continue to develop rapidly require the mastery of good English so that students can be independent and able to choose learning materials according to their own needs. [1] explains that reading is a complex activity by mobilizing a large number of separate actions. [2] explains that reading is an activity or cognitive process that seeks to find various information contained in writing.

[3a] reveals that the development of science and technology requires human resources to be able to overcome problems due to changes in life by generating ideas and ideas that can overcome these problems. To achieve this, a person must know his knowledge and recognize his own abilities. [4a] reveals that human needs for education are a basic need in order to prepare every human being to a level where they are able to demonstrate responsible independence, both for themselves and their environment. Based on one view that through education, humans prove themselves as creatures that continue to develop. Through human 
education developed from before only had the potential that had no meaning whatsoever, but with education they developed to become more perfect and continue to perfect themselves.

Reading skills in English requires learning to require precision, perseverance, and continuous learning. This is because reading English, especially those who are new to English text requires perseverance in learning so that they are able to recognize the vocabulary and problems in English texts continuously. The problems that exist in English language learners who are outside the English Language Education program are learning objectives and more limited learning time with English education study programs which from the beginning to the end of learning English This study focused on pendidikan bahasa and sastra Indonesia program at Muria Kudus University which contains English courses starting from semester 1 to semester 4 with English language skills learned, listening, speaking, reading and writing.

Learning English in Indonesian language and literature education courses requires innovation in learning English because they tend to lack interest in learning English. One of the reasons for this is because English is considered difficult to understand than learning other subjects.

The habits that exist in students to get to know English more deeply are also less enthusiastic because it is considered that English needs are few in lectures. The importance of providing the latest innovations in learning English especially in reading skills is important to do. One of the solutions to spur students to learn English is to use metacognitive strategies. [5b] explains that metacognitive strategies are a form of a person's ability to see his own abilities, and control them so that what is done is optimal. [6b] shows that metacognition is a process that includes three different stages, and to be a successful thinker, students must do the following: 1). Develop a plan before doing learning, such as reading for understanding or solving problems, 2). Monitor understanding by using strategies when solving problems, 3) evaluating students' thinking after completing assignments.

[7a] explains that metacognitive strategies include (1) advance organization, which means a preliminary review of the main ideas and concepts of the material to be studied; (2) advance preparation (meaning preparation), which means training the language needed for oral or written assignments; (3) organizational planning (organizational planning), which means planning parts, sequences, and main ideas that will be expressed verbally or in writing; (4) selective attention, which means following or skimming key words, linguistic marker phrases, sentences, or types of information; (5) self-monitoring (swapantau), which means checking one's understanding during listening or reading, oral or written production; (6) self-evaluation, which means evaluating how well someone completes a learning task; (7) self-management (meaning self-management), which means finding or arranging conditions that help a person learn, for example finding opportunities for additional input and training in language and content. In line with [8b] this study uses the phasing of metacognitive strategies to improve English reading skills of pendidikan dan sastra Indonesia students at Muria Kudus University.

The research conducted by [9] entitled "The Effect of Metacognitive Strategy on Mathematics in the Problem Solving Ability in Eighth Grade Students of Yogyakarta Public Middle School 6", shows the importance of using metacognitive strategies in learning.

Based on the problems described, in this paper the researcher focuses on the "Learning Patterns of Reading English through Metacognitive Strategies in the Industrial Age 4.0". The purpose of this study was first to find out about the current English reading learning. Second, knowing the pattern of learning to read English through metacognitive strategies in the industrial era 4.0. 


\section{Method}

The method used in this study is a qualitative method. This research data in the form of interviews and documentation. Interviews were conducted to PBSI UMK students randomly to obtain valid information. Documentation was obtained from midterm and final exam results on English reading skills. Data analysis using the theory of [10] namely data reduction, data presentation, and drawing conclusions. Data analysis in this study was carried out in stages so that valid and credible data analysis was obtained.

\section{Results and Discussion}

This study produced two findings that were used as discussion in this paper. 1. Learning to Read English That Happens Now

Reading skills that occur at this time in students are often having difficulty in understanding reading texts because of lack of interest in learning English. This difficulty has made it difficult for students from pendidikan dan sastra Indonesia University of Muria Kudus to develop in terms of understanding English-language reading and it is difficult to improve their vocabulary. This self-distrust and willingness to develop made students become passive in learning so they did not dare to issue their abilities in terms of activeness in class.

English is considered a foreign language so that it is not applied in daily life. Based on the results of interviews with pendidikan dan sastra Indonesia Education students at Muria Kudus University, it is known that the attitude of loving English is not fully owned by students because of the causes of perseverance that have not yet emerged and often assume that English is scary because it is difficult to understand.

Learning to read English which has been taught so far has used models and media in learning, but the difficulties experienced by students in learning still occur due to the activity, interest, and learning that are considered to not facilitate students because of the different abilities of students. There are students who have good English language skills in terms of reading English text skills and there are those whose abilities are still moderate and sufficient.

The attitude of students' self-confidence needs to be guided and improved by inviting students to practice directly not only in class but outside the classroom with an individual approach. Learning like this can improve the ability of students to be better. [11] reveal that self-confidence is the most valuable attribute in a person in social life, because with the existence of self-confidence, a person is able to actualize all the potential within him. This self-confidence can also be influenced by abilities and skills possessed. Students who have high self-confidence will easily interact with other students, be able to express opinions without any doubts and respect the opinions of others, are able to act and positive thinking in decision making, whereas students who have low self-confidence will find it difficult to communicate, argue, and will feel that he cannot compete with other students.

\section{Learning Patterns Reading English through a Metacognitive Strategy in the Industrial Age} 4.0

One of the factors that can improve the ability to read English is using a metacognitive strategy. The learning pattern of English reading skills in this study uses a metacognitive strategy developed by [12c]. Through this metacognitive strategy, learning is more effective, students are. 
a) advance organization

At this stage, advancing learning organizations is carried out by providing new learning concepts that are favored by students and can be well received by the purpose of learning to read the skills implemented. Through the use of objects that are around the class, learning can be easily identified directly with the characteristics, forms, and value of their usefulness.ore active, and learning outcomes in English reading skills also increase.

b) advance preparation (improving preparation)

At this stage, advance preparation is done by increasing the present simple and present continuous tense. Examples of present simple tense: I love writing very much (+), I do not love writing very much (-), do you love writing very much (?), Example of present continuous tense: he is writing novel (+), they are not listening to you (-), are you eating my chocholate? (?) use words that are often encountered or used so learning can be easily remembered.

c) organizational planning (organizational planning)

At this stage present simple tense and continuous tense learning with sequences using the SQ3R technique (Survey, Question, Read, Recite and Review). [13] explains that the SQ3R Method (Survey, Question, Read, Recite, and Review) is a method of learning or how to study texts (readings) specifically contained in books, scientific articles, and research reports specifically to understand the contents of the text. The SQ3R learning method is also interpreted as tips for learning texts with examination steps, making a list of questions, reading actively, understanding each answer to the question, and reviewing the answers to all questions. This method has advantages such as being able to concentrate more on reading and understanding the contents of the material better.

The survey is conducted by looking at the situation in the classroom and the habits and habits in the classroom so that it can bring new ideas into learning. In this study the results of the survey were used as learning material. Question is done by inviting active students to make questions from Indonesian to English according to their classroom environment and habits. Read, in the form of action to read the concept of simple tense and countinous tense which will be used as learning material. Recite is done by repeating simple tentse material and material and ontinous tenses that will be used in learning so that the preparation of learning will be more mature. The review was carried out together with the lecturers' work carried out by students so that each student had prepared the present simple tense and continuous tense material.

d) selective attention

At this stage selective attention is carried out by displaying media in the form of images that contain activities in the classroom through the use of picture media so that understanding the present simple tense material and continuous tense will be easily understood in learning.

e) self-monitoring (monitoring)

At this stage self-monitoring controls the use of image media in recording understanding of the present simple tense and continuous tense material.

f) self-evaluation

This stage is used to evaluate present simple tense and continuous tense learning. In this study researchers used authentic assessments. Authentic research is used to collect data on both abilities and shortcomings possessed by students in learning English reading skills. [14] reveals that authentic assessment is a form of assessment that asks students to apply concepts or theories to the real world. Authentic means the real situation, namely the ability or skill possessed by students. [15] reveals that the nature of authentic assessment is the process of collecting various data that can provide an overview of student learning progress.

g) self-management (self-management), 
At this stage it is used for reflection of the stages carried out by the metacognitive strategy so that if there are shortcomings and weaknesses in learning it will be immediately known and resolved as soon as possible.

\section{Conclusion}

Learning English becomes an important element to be mastered by students. Language as a communication tool needs to be mastered as a provision of language skills that can be used to expand knowledge. Reading skills as one of the elements of language skills that support other skills are important to make as a foundation in learning other skills. Metacognitive strategies as one of the strategies in developing student abilities is a strategy to improve the ability to read the right English to practice reading knowledge based on the experience and activeness of the learners themselves. 


\section{References}

[1] Soedarso. Speed Reading Sistem Membaca Cepat dan Efektif. Jakarta: Pt Gramedia Pustaka Utama. (2010).

[2] Dalman. Keterampilan Membaca. Jakarta: Rajawali Pers. (2014).

[3a] Roza, M. Penerapan Strategi Pembelajaran Metakognitif Terhadap Kemampuan Penalaran Matematis Siswa Kelas XI IPS SMA Negeri 1 Talamau Kabupaten Pasaman Barat. Jurnal Kepemimpinan dan Pengurusan Sekolah, 2(1), hlm. 39-48. (2017).

[4a] Fithriyana, E. Peran Strategi Metakognitif dengan Bantuan Metode PQ4R Pada Prestasi Akademik Mahasiswa PIAUD di Institut Agama Islam Sunan Giri Bojonegoro. Al Ulya: Jurnal Pendidikan Islam, 3(2), hlm. 162-171). (2018)

[5b] Roza, M. Penerapan Strategi Pembelajaran Metakognitif Terhadap Kemampuan Penalaran Matematis Siswa Kelas XI IPS SMA Negeri 1 Talamau Kabupaten Pasaman Barat. Jurnal Kepemimpinan dan Pengurusan Sekolah, 2(1), hlm. 39-48. (2017).

[6b] Fithriyana, E. Peran Strategi Metakognitif dengan Bantuan Metode PQ4R Pada Prestasi Akademik Mahasiswa PIAUD di Institut Agama Islam Sunan Giri Bojonegoro. Al Ulya: Jurnal Pendidikan Islam, 3(2), hlm. 162-171). (2018)

[7a] Nurwicaksono, B.D.. Penerapan Kolaborasi Strategi Metakognitif dalam Meningkatkan Hasil Belajar Siswa pada Materi Menulis Karya Ilmiah. Education and Human Development Journal, 2(2), hlm. 15-22. (2017)

[8b] Nurwicaksono, B.D.. Penerapan Kolaborasi Strategi Metakognitif dalam Meningkatkan Hasil Belajar Siswa pada Materi Menulis Karya Ilmiah. Education and Human Development Journal, 2(2), hlm. 15-22. (2017)

[9] Prasetyoningrum, F.D., Mahmudi, A. The Effect of Metacognitive Strategy on Mathematival Problem Solving Ability in Eighth Grade Students of SMP Negeri 6 Yogyakarta. Jurnal Pendidikan Matematika, 6(4), hlm. 19-27. (2017).

[10] Romadhoni, F. Pola Komunikasi di Kalangan Pecandu Game Let's Get Rich di Komunitas Xlite Tenggarong. Jurnal Ilmu Komunikasi, 5(1), hlm. 235-247. (2017).

[11] Syam, A., Amri. Pengaruh Kepercayaan Diri (Self Confidence) Berbasis Kaderisasi Imm Terhadap Prestasi Belajar Mahasiswa (Studi Kasus di Program Studi Pendidikan Biologi Fakultas Keguruan dan Ilmu Pendidikanuniversitas Muhammadiyah Parepare). Jurnal Biotek, 5(1), hlm. 87102. (2017).

[12c] Nurwicaksono, B.D.. Penerapan Kolaborasi Strategi Metakognitif dalam Meningkatkan Hasil Belajar Siswa pada Materi Menulis Karya Ilmiah. Education and Human Development Journal, 2(2), hlm. 15-22. (2017)

[13] Masykur., Khanafiyah, S., Handayani, L. Penerapan metode SQ3R dalam pembelajaran kooperatif untuk meningkatkan hasil belajar Fisika pokok bahasan tata surya pada siswa kelas VII SMP. Jurnal Pendidikan Fisika Indonesia, 4(2), hlm. 73-78. (2016).

[14] Mardapi, D. Pengukuran, Penilaian, dan Evaluasi Pendidikan (Edisi Revisi). Yogyakarta: Parama Publishing. (2017).

[15] Masrukan. Asesmen Otentik Pembelajaran Matematika, Mencakup Asesmen Afektif dan Karakter. Semarang: FMIPA Unnes. (2014). 